\title{
ASSESSING THE ACCEPTANCE BY TOURISM AND HOSPITALITY STUDENTS OF JORDANIAN UNIVERSITIES' CONTRIBUTION TO THEIR TRAINING AND EMPLOYMENT
}

\author{
Mairna Mustafa* \\ Hashemite University, Queen Rania Faculty of Tourism and Heritage, Department of \\ Sustainable Tourism, P.O. Box 330127 Postal Code 13115 Zarqa, Jordan, e-mail: mairna@hu.edu.jo
}

\begin{abstract}
Citation: Mustafa, M. (2019). ASSESSING THE ACCEPTANCE BY TOURISM AND HOSPITALITY STUDENTS OF JORDANIAN UNIVERSITIES' CONTRIBUTION TO THEIR TRAINING AND EMPLOYMENT. GeoJournal of Tourism and Geosites, 25(2), 375-382. https://doi.org/10.30892/gtg.25208-366
\end{abstract}

\begin{abstract}
This paper aims at evaluating students' acceptance of universities' contribution to their training and employment. Such contribution is achieved through communication and collaborating with the tourism and hospitality enterprises. A sample of 120 students in Tourism and Hospitality Management Programs in Jordanian universities filled a questionnaire that focused on aspects related to study plans, training and following up with graduates on their employment progress. A general low level of acceptance is indicated by results regarding courses content, training provided while pursuing the degree and coordinating with employment market. It is recommended that universities should give more priority to enhancing their programs' quality through more involvement of the industry in the design of curricula and students' training, as well as facilitating the access of students to jobs.
\end{abstract}

Key words: tourism and hospitality education, students acceptance, students satisfaction, tourism training and employment, Jordanian Universities

INTRODUCTION

The hospitality and tourism industries are significant contributors to the economies and employment worldwide; they require educated, skilled and committed workforce for their success. A significant source of such workforce is colleges and universities offering educational programs to qualify human resources to work in these industries. These provide education and training programs of various lengths in the form of both theoretical and vocational training courses (Koyuncu et al., 2008).

For Jordan, tourism and hospitality as educational disciplines are included as academic programs in 13 public and private universities, 9 community colleges; 17 tourism and hospitality training centers and 27 public and private schools (USAID, 2007).

\footnotetext{
* Corresponding author
} 
Since 2012, the Higher Education Accreditation Commission in Jordan formally declared that universities solely have the choice to open one or more of 3 majors (Tourism Management; Hotel Management and Events Management). To be nationally accredited, any of these programs should commit to particular standards for course disciplines, practical training/internship and training facilities in their establishments. Such accreditation standards enhanced the quality of curricula, training and other inputs, but it did not necessarily improve aspects related to the involvement of tourism/hospitality industry in facilitating training and employment of students.

Jordan, as many other countries is facing the problem of non-consonance between the needs of employers and the educational outcomes of universities offering the professions of tourism and hospitality (Mustafa, 2012). As stated by Mustafa et al., 2017 it is a reality that universities and colleges are being perceived as being too academic, where their teaching skills and topics are in isolated context, not necessarily including the basic and potential skills on how to run a business; moreover, there is a lack of coordination with private sector in different stages of curricula development, training and recruitment. Most of these programs focus on preparing students for managerial positions without sufficiently considering problem identification, communication, analytical, creativity and leadership skills. In many cases these universities lack technical facilities as laboratories and technology to support the curriculum. This is due to different factors; one is that such majors are housed in diverse fields as geography, sociology, natural resources management, and business studies. Many institutes and universities perceive the introduction of new tourism programs as important only to increase students' enrolment. Also, the lack of proper academic understanding and focused theoretical framework of most tourism studies leads to unclear directions in the teaching tourism courses (Mayaka \& Akama, 2007). Tourism and hospitality fields are applied subject areas that require academics, students and curricula developers to have close links with tourism industry. This is not the actual case of many educational programs where strategies for industry engagement are haphazard and lack commitment (Solnet et al., 2007).

This means that tourism institutions will not be able to develop programs that help students move ahead in an orderly way; many tourism students find themselves in tedious dead-end jobs, making the education and training they have received not of any relevance (Berger, 2008). In some cases, tourism industry is often seeking cheap labor, while the educational institution focuses on a structured training experience for the student. Therefore, partnerships founded on these outcomes lack strategic direction and do not fully meet the expectations of the educator, the industry and the student (Solnet et al., 2007). Tourism education in Jordan is facing these problems (Mustafa, 2012); consequently, employing tourism programs' graduates by the industry is far below its potential.

\section{Tourism Education and Students' Satisfaction}

The four main stakeholders to be involved in the design, development and implementation of educational programs are: enterprises (industry), students, educational institutions and government (Zagonari, 2009). Industry particularly should have a key role in the design and delivery of the tourism curricula, educators then act as the conduit between industry and students beside their role of providing quality education as a first priority. Students will achieve a better representation in the industry if they develop contacts with it, and if they have a good educational experience (Dale \& Robinson, 2001). According to Goodenough and Page (1993) there is an urgent need for a closer contact between the industry and the educational provider to develop the training requirements of course participants, though, such role is time consuming and demanding for academics, causing then a weak relation with the industry. 
The satisfaction of students on quality of educational process became significant to numerous research works, which dealt with different aspects such as: institutional image (Bringula \& Basa 2010; Brown \& Mazzarol, 2009), teaching methods (Abdullah, 2006; Baum, 1991; Burbidge, 1994; Dimmock et al., 2003; Knutson, 1992; Lee et al., 2009; Munar \& Montano, 2009; Moscardo, 1997; Wang et al., 2010), training (Arif et al, 2013; Gruber et al., 2010), evaluation process (Sultan \& Wong, 2012), competencies achieved by programs (Mustafa et al., 2017), admission procedures (Sultan ${ }^{\wedge}$ Wong, 2012), and coordination with employers (O'Driscoll, 2012). Moreover, different instruments were developed to measure the satisfaction of higher education and vocational students; these include: The Student Outcomes Survey in Australia (Fieger, 2012), British National Student Survey (NSS) (Ipsos MORI, 2019), the American National Survey of Student Engagement (NSSE) (Indiana University School of Education, 2019), HEdPERF and SERVPERF (Abdullah, 2006), and European Customer Satisfaction index (ECSI) (ECSI Technical Committee, 1998). According to Băcilă et al., (2014), education managers need to measure the students' level of satisfaction in order to assess their performance, though, this is not easy to achieve since satisfaction is an abstract concept and was not clearly defined or measured. Many definitions were given to the concept of satisfaction; generally, it is a feeling generated from an evaluation of the use experience (Cadotte et al., 1987); Oliver (1997) defined it as the judgement that a provided product is of a pleasurable level of consumption.

It was also recognized as the "consumer's response to the evaluation of the perceived discrepancy between prior expectations and the actual performance of the product as perceived after its consumption (Tse \& Wilton, 1988: p. 204), while Fornell (1992) stated that satisfaction is "an overall post-purchase evaluation" (p.11). Overall, satisfaction represents the response of the end user (Giese \& Cote, 2002).

It is an evaluation process, regardless of the context or targeted group. Considering that the targetd sample of students in this research were still pursuing their Bachelor degree, it was more appropriate then to use the concept of acceptance; according to Nielsen (1993) (as cited by Adell, 2007, 2), an acceptance is the "the question of whether the system is good enough to satisfy all the needs and requirements of the users and other potential stakeholder"; thus, the end use of the tourism program as an educational product was not yet achieved. The aim of this research is to evaluate the acceptance levels of students regarding the performance of their universities in the following aspects: their collaboration with tourism/hospitality industry for training and employment of students, also the study plans' coverage of some knowledge areas and skills needed for future jobs (the measured variables were derived from previous literature and rephrased for the purposes of this study).

\section{MATERIALS AND METHODS}

A random sample of 120 students in 3 Jordanian universities (2 private and 1 public) were targeted to fill the questionnaire of this study. In the time when the survey was distributed in 2010, a random sample of 120 was decided (by calculating the sample size needed with a confidence level of $95 \%$ and a confidence interval of 10 , it should be at least 96). This sample was divided into two subgroups: 60 students from a public university, and 60 from 2 private universities. A research assistant was trained to introduce the questionnaire to the targeted respondents and help in filling them. 110 students responded: 56 out of 60 in private universities' group, and 54 out of 60 in the public university group (\%91.6 as a total response rate), data collection took place at the campuses of these universities. 56 respondents were students enrolled in hotel 
management, while 54 were in tourism management. Most of the students in the sample were in their 3 rd or 4 th year. 69 were males and 38 were females, 106 of the sample were in the age range of 20-25, only 3 were 26-30 years old.

The research instrument was designed to include the following sections: The first section was for information about respondent like age, level of study and gender. The second section included questions with dichotomous responses (yes/no), these questions aimed to know: if students worked in tourism, if they had to make more self efforts to gain skills for future jobs in tourism, if the faculty helped them in searching for jobs opportunities, if they recommend such major to others, if they have taken yet the practical training of their study, and if they think that their study plans should be modified to better fit employment market needs. The third section was an index of educational inputs to be evaluated by students on a five-point scale (1: Completely Acceptable, 2: Very Acceptable, 3: Moderately Acceptable, 4: Slightly Acceptable and 5: Not At All Acceptable), and these were concerning: tourism courses credits versus other specialization credits in study plan, specialization credits versus university requirements, theoretical versus practical credits, number of practical training credits, the coverage of some topics by the study plan, the communication between faculty and students to follow up on the their employment, the communication between faculty and employers in tourism for the purpose of practical training, and the communication by faculty with tourism employers in order to facilitate the employment of students. The Cronbach's alpha for this 13-items scale was (0.887), (with a summary mean of 3.066 and a variance of 0.324 ). The respondents were asked to add comments if they had any after filling the questionnaire.

\section{RESULTS \& DISCUSSIONS}

The results show that most of the respondents in the sample did not have the chance at that time to get employed in tourism while studying (only 43 out of 110), also, only 50 of them took the practical training/internship course.

Though, the responses of students to questions on university role in training and employment reflected a weakness by the programs in such aspects (Table 1). 60 students agreed that courses provided by the university equipped them with skills to work in tourism, though, 71 students think that they needed more self efforts to enhance such skills. 79 students stated that their university did not have any role in helping them to find jobs in tourism and hospitality industry. Only 56 respondents would recommend the major they studied to others. Moreover, 86 respondents think that their study plan should be modified to better fit employment market needs.

Table 1. The responses of students to dichotomous questions on university contribution to training and skills gained through study program

\begin{tabular}{|l|c|c|c|}
\hline \multicolumn{1}{|c|}{ Question } & Yes & No & $\begin{array}{c}\text { N of Valid } \\
\text { Responses }\end{array}$ \\
\hline Have you got the chance to work in your field of study? & 43 & 67 & 110 \\
\hline $\begin{array}{l}\text { Have the courses you have taken in the university equipped you with } \\
\text { needed skills for working in tourism? }\end{array}$ & 60 & 47 & 107 \\
\hline $\begin{array}{l}\text { Have you needed to make more self efforts to equip yourself with } \\
\text { necessary skills for future tourism jobs? }\end{array}$ & 71 & 35 & 106 \\
\hline Has your school taken any role in searching for jobs opportunities in tourism? & 25 & 79 & 104 \\
\hline Do you recommend your major for others? & 56 & 51 & 107 \\
\hline Have you taken yet the practical training of your study? & 50 & 59 & 109 \\
\hline $\begin{array}{l}\text { Do you think your study plan should be modified to better fit } \\
\text { employment market needs? }\end{array}$ & 86 & 21 & 107 \\
\hline
\end{tabular}


For the evaluation regarding program credits, training and communication of university with different stakeholders. It can be noticed that 7 of the variables in this index had mean scores between 3 (Moderately Acceptable) and 4 (Slightly Acceptable), while 6 variables had means between 2 (Very Acceptable) and 3 (Moderately Acceptable), which generally does not reflect a high level of acceptance (Table 2). The items that had the highest means were for the number of offered practical training credits ( $\mathrm{M}=3.7547, \mathrm{SD}=1.31520)$, the evaluation of university's communication with the industry to train students $(\mathrm{M}=3.7525, \mathrm{SD}=1.28379)$, and the coverage of foreign languages (other than English) $(\mathrm{M}=3.6436, \mathrm{SD}=1.21313$ ), (i.e. between Moderately Acceptable and Slightly Acceptable). The items that had the lowest means were for the coverage of topics related to tourism services and sites in Jordan ( $\mathrm{M}=2.4019$, $\mathrm{SD}=1.08419$ ), and the number of tourism credits versus other credits in the study plan $(\mathrm{M}=2.4312, \mathrm{SD}=1.03965)$ (i.e. between Very Acceptable and Moderately Acceptable).

Table 2. Descriptive statistics of variables related to acceptance of credit hours and study plan topics

\begin{tabular}{|l|c|c|c|}
\hline \multicolumn{1}{|c|}{ Question } & $\mathrm{N}$ & Mean & $\mathrm{SD}$ \\
\hline $\begin{array}{l}\text { How do you evaluate the number of tourism credits if compared to } \\
\text { other courses credits in your study plan? }\end{array}$ & 109 & 2.4312 & 1.03965 \\
\hline $\begin{array}{l}\text { How do you evaluate the number of specialization credits if } \\
\text { compared to university and faculty requirements? }\end{array}$ & 107 & 2.6542 & 1.01964 \\
\hline $\begin{array}{l}\text { How do you evaluate the number of theoretical courses credits if } \\
\text { compared to practical ones? }\end{array}$ & 107 & 3.6075 & 1.33711 \\
\hline How do you evaluate the number of practical training credits? & 106 & 3.7547 & 1.31520 \\
\hline How do you evaluate the coverage of theoretical aspects of tourism? & 105 & 2.4952 & 1.08419 \\
\hline How do you evaluate the coverage of communication skills? & 108 & 2.7222 & 1.09231 \\
\hline How do you evaluate the coverage of English language skills and topics? & 106 & 3.3868 & 1.26920 \\
\hline How do you evaluate the coverage of Other languages skills and topics? & 101 & 3.6436 & 1.21313 \\
\hline $\begin{array}{l}\text { How do you evaluate the coverage of topics related to sites and } \\
\text { tourism services in Jordan? }\end{array}$ & 107 & 2.4019 & 1.08905 \\
\hline $\begin{array}{l}\text { How do you evaluate the coverage of other related topics as } \\
\text { archaeology, management ...etc? }\end{array}$ & 107 & 2.5047 & 1.12748 \\
\hline $\begin{array}{l}\text { How do you evaluate the communication of college to check your } \\
\text { work progress? }\end{array}$ & 101 & 3.7525 & 1.28379 \\
\hline $\begin{array}{l}\text { How do you evaluate the communication of college with tourism } \\
\text { industry for practical training? }\end{array}$ & 105 & 3.3619 & 1.35961 \\
\hline $\begin{array}{l}\text { How do you evaluate the communication of your college with } \\
\text { tourism sectors for employing students? }\end{array}$ & 105 & 3.4571 & 1.33033 \\
\hline
\end{tabular}

Note: the variables in this table were measured on the following scale: (1: Completely Acceptable, 2: Very Acceptable, 3: Moderately Acceptable, 4: Slightly Acceptable and 5: Not At All Acceptable)

The analysis was further extended in order to understand if there are differences in acceptance levels between private and public universities' students. Both Crosstabulation (for dichotomous variables) and T-test (for the acceptance 5-point scale variables) were conducted for this purpose. For Crosstabulation (Table 3), some of the variables had significant $\mathrm{p}$ values (less than or equal to 0.05) indicating an association between students' responses and being in a public or a private university; these were: if they had the chance to work in the industry, 37 of 56 students in private universities answered with yes versus 19 in public university group ( $\chi 2=34.876, p=.000$ ), if the university courses equipped them with needed skills to work in tourism, 36 students in private universities group agreed versus 24 in public university group $(\chi 2=4.966, p=.026)$, and if they 
recommend the major to others, 35 students in the private university group stated that they would versus 21 students in the public university group $(\chi 2=5.793, p=.016)$.

Table 3. Crosstabulation between university type and responses

on contribution to training and skills gained through study program

\begin{tabular}{|c|c|c|c|c|c|c|}
\hline \multirow{2}{*}{ Question } & \multirow{2}{*}{ Answer } & \multicolumn{2}{|c|}{ University } & \multirow[b]{2}{*}{$x^{2}$} & \multirow[b]{2}{*}{$\mathrm{p}$} & \multirow{2}{*}{ Eta } \\
\hline & & \begin{tabular}{|l|} 
Private \\
\end{tabular} & Public & & & \\
\hline \multirow{2}{*}{$\begin{array}{l}\text { Have you got the chance to work in your field of } \\
\text { study? }\end{array}$} & Yes & 37 & 6 & \multirow{2}{*}{34.876} & \multirow{2}{*}{.000} & \multirow{2}{*}{.563} \\
\hline & No & 19 & 48 & & & \\
\hline \multirow{2}{*}{$\begin{array}{l}\text { Have the courses you have taken in the university } \\
\text { equipped you with needed skills for working in tourism? }\end{array}$} & Yes & 36 & 24 & \multirow{2}{*}{4.966} & \multirow{2}{*}{.026} & \multirow{2}{*}{.215} \\
\hline & No & 18 & 29 & & & \\
\hline \multirow{2}{*}{$\begin{array}{l}\text { Have you needed to make more self efforts to equip } \\
\text { yourself with necessary skills for future tourism jobs? }\end{array}$} & Yes & 37 & 34 & \multirow{2}{*}{.118} & \multirow{2}{*}{.732} & \multirow{2}{*}{.033} \\
\hline & No & 17 & 18 & & & \\
\hline \multirow{2}{*}{$\begin{array}{l}\text { Has your school taken any role in searching for } \\
\text { jobs opportunities in tourism? }\end{array}$} & Yes & 14 & 11 & \multirow{2}{*}{0.219} & \multirow{2}{*}{$\mid .640$} & \multirow{2}{*}{.046} \\
\hline & No & 40 & 39 & & & \\
\hline \multirow{2}{*}{ Do you recommend your major for others? } & Yes & 35 & 21 & \multirow{2}{*}{$5 \cdot 793$} & \multirow{2}{*}{$\mid .016$} & \multirow{2}{*}{.233} \\
\hline & No & 20 & 31 & & & \\
\hline \multirow{2}{*}{$\begin{array}{l}\text { Have you taken yet the practical training of your } \\
\text { study? }\end{array}$} & Yes & 38 & 12 & \multirow{2}{*}{22.41} & \multirow{2}{*}{.000} & \multirow{2}{*}{.454} \\
\hline & No & 18 & 41 & & & \\
\hline \multirow{2}{*}{$\begin{array}{l}\text { Do you think your study plan should be modified to } \\
\text { better fit employment market needs? }\end{array}$} & Yes & 44 & 42 & \multirow{2}{*}{.466} & \multirow{2}{*}{.495 } & \multirow{2}{*}{.066} \\
\hline & No & 9 & 12 & & & \\
\hline
\end{tabular}

Table 4. T-test comparisons between private and public

universities' students on acceptance of credit hours and study plan topics

\begin{tabular}{|c|c|c|c|c|c|c|}
\hline Question & Uni. & $\mathrm{N}$ & $\mathrm{M}$ & SD & $\mathrm{t}$ & $\mathrm{p}$ \\
\hline \multirow{2}{*}{$\begin{array}{l}\text { How do you evaluate the number of tourism credits if } \\
\text { compared to other courses credits in your study plan? }\end{array}$} & Private & 55 & 2.4909 & 1.05185 & \multirow{2}{*}{.603} & \multirow{2}{*}{.548} \\
\hline & Public & 54 & 2.3704 & 1.03334 & & \\
\hline \multirow{2}{*}{$\begin{array}{l}\text { How do you evaluate the number of specialization credits } \\
\text { if compared to university and faculty requirements? }\end{array}$} & Private & 53 & & 1.11397 & \multirow[b]{2}{*}{2.595} & \multirow[b]{2}{*}{.011} \\
\hline & Public & 54 & 2.4074 & .85822 & & \\
\hline \multirow{2}{*}{$\begin{array}{l}\text { How do you evaluate the number of theoretical } \\
\text { courses credits if compared to practical ones? }\end{array}$} & Private & 53 & 3.4151 & 1.40650 & \multirow[b]{2}{*}{-1.483} & \multirow[b]{2}{*}{.141} \\
\hline & Public & 54 & 3.7963 & 1.24960 & & \\
\hline \multirow{2}{*}{$\begin{array}{l}\text { How do you evaluate the number of practical training } \\
\text { credits? }\end{array}$} & Private & 55 & 3.6364 & 1.33837 & \multirow[b]{2}{*}{-.962} & \multirow{2}{*}{.338} \\
\hline & Public & 51 & 3.8824 & 29069 & & \\
\hline \multirow{2}{*}{$\begin{array}{l}\text { How do you evaluate the coverage of theoretical } \\
\text { aspects of tourism? }\end{array}$} & Private & 53 & & 08493 & \multirow{2}{*}{-.224} & \multirow{2}{*}{.824} \\
\hline & Public & 52 & & 99348 & & \\
\hline \multirow{2}{*}{$\begin{array}{l}\text { How do you evaluate the coverage of communication } \\
\text { skills? }\end{array}$} & Private & 54 & 22 & 82 & \multirow{2}{*}{.000} & \multirow{2}{*}{1.000} \\
\hline & Public & 54 & & 602 & & \\
\hline \multirow{2}{*}{$\begin{array}{l}\text { How do you evaluate the coverage of English language } \\
\text { skills and topics? }\end{array}$} & Private & 55 & 3. & 1106 & \multirow[b]{2}{*}{1.816} & \multirow[b]{2}{*}{.072} \\
\hline & Public & 51 & 9 & 188 & & \\
\hline \multirow{2}{*}{$\begin{array}{l}\text { How do you evaluate the coverage of Other languages } \\
\text { skills and topics? }\end{array}$} & Private & 53 & & 53 & \multirow[b]{2}{*}{3.059} & \multirow[b]{2}{*}{.003} \\
\hline & Public & 48 & 8 & 23322 & & \\
\hline \multirow{2}{*}{$\begin{array}{l}\text { How do you evaluate the coverage of topics related to } \\
\text { sites and tourism services in Jordan? }\end{array}$} & Private & 54 & & & \multirow[b]{2}{*}{.053} & \multirow{2}{*}{.958} \\
\hline & Public & 53 & 2.3962 & & & \\
\hline \multirow{2}{*}{$\begin{array}{l}\text { How do you evaluate the coverage of other related } \\
\text { topics as archaeology, management ...etc? }\end{array}$} & Private & 54 & & 315 & \multirow[b]{2}{*}{-.900} & \multirow[b]{2}{*}{.370} \\
\hline & Public & 53 & 2.6038 & 23 & & \\
\hline \multirow{2}{*}{$\begin{array}{l}\text { How do you evaluate the communication of college to } \\
\text { check your work progress? }\end{array}$} & Private & 52 & 3.7308 & 1.20644 & \multirow[b]{2}{*}{-.174} & \multirow[b]{2}{*}{.862} \\
\hline & Public & 49 & 3.7 & & & \\
\hline & Private & 54 & 3.3704 & 1.40479 & & \\
\hline & Public & 51 & & & & .94 \\
\hline $\begin{array}{l}\text { How do you evaluate the communicati } \\
\text { college with tourism sectors for employ }\end{array}$ & Private & 55 & 3.5636 & 1.33 & .859 & .392 \\
\hline
\end{tabular}


The results of the T-test showed that only 2 variables were of significant differences for the acceptance levels by the two groups of private and public universities, these were for: the number of specialization credits compared to university and faculty requirements $(\mathrm{t}=2.595, \mathrm{p}=.011)$, and the coverage of foreign languages skills (other than English), one variable was close though to statistical significance, that was for the coverage of English language skills $(t=1.816, p=.072)$, where means were higher for private universities group, indicating then a lower acceptance level (Table 4).

\section{CONCLUSION}

Such results initiate the need to put more efforts by Jordanian universities to train and introduce students to employment market; more communication and coordination with employers in tourism and hospitality business should take place, where their needs and expectations are considered during the stages of curricula design, training and job selection. Not less important is improving the quality of the programs to acquaint students with necessary skills needed for tourism careers. This becomes more important if we consider that there is a general low level of satisfaction among Jordanian tourism and hospitality employers regarding educational outputs of university programs, as well as the degree of communication between universities and the industry to facilitate training and employment (Mustafa, 2012). Some clear differences could be noticed between the responses of students in private and public universities; private universities are exceeding public universities in terms of training facilities and connections with private sector, which explains the higher agreement frequencies (Table 3) and acceptance levels (Table 4) by students in private universities' group. Though, private universities are in most cases offering tourism and hospitality management programs through their schools of business, this is reflected in their faculty compulsory courses, which usually include general courses on accounting, management, economics, and finance; this might explain the low level of acceptance among students for the number of specialization credits, the same can be said about English and other foreign languages, where public universities provide more of these with several levels. This indicates the urgent need to improve educational inputs by both public universities (training and facilitating employment) and private universities (study plan course topics and coherence).

\section{REFERENCES}

Abdullah, F. (2006). Measuring Service Quality in Higher Education: HEdPERF versus SERVPERF. Marketing Intelligence \& Planning, 24(1), 31-47.

Adell, E. (2007). The concept of Acceptance. 2oth ICTCT Workshop, Valencia, Spain, 2007/10/25.

Arif, S., Ilyas, M. \& Hameed, A. (2013). Student Satisfaction and Impact of Leadership in Private Universities. The TQM Journal, 25 (4), 399-416.

Bacila, M., Ciornea, R., Marcel, P., \& Mircea Andrei, S. (2014). Development of an Instrument for Measuring Student Satisfaction in Business Educational Institutions. Amfiteatru Economic, 16, 677-691.

Bappah, A. \& Medugu, D. (2013). Employers' Perception of the Role of Technical Vocational Education and Training in Sustainable Development in Nigeria. Journal of Research \& Method in Education, 2(3), 1-5.

Baum, T. (1991). The US and the UK: Comparing Expectations of Management Trainees'. The Cornell H.R.A. Quarterly, 32(1), 79-84.

Berger, A. (2008). Tourism in Society. Society, 45(4), 327-329.

Bringula, B.P., \& Basa R.S., 2010. Institutional Image Indicators of Three Universities: Basis for Attracting Prospective Entrants. Educational Research for Policy and Practice, 10 (1), 53-72.

Brown, R., \& Mazzarol, T. (2009). The importance of institutional image to student satisfaction and loyalty within higher education. Higher Education, 58, 81-95.

Burbidge, D. (1994). 'Student Perception of Preparation for Success: A View from Europe'. Hospitality \& Tourism Educator, 4(4), 45-50. 
Cadotte, E., Woodruff, R. \& Jenkins, R. (1987). Expectations and Norms in Models of Consumer Satisfaction, Journal of Marketing Research, 24, 305-314.

Dale, C., \& Robinson, N. (2001). The Theming of Tourism Education: a Three-domain Approach. International Journal of Contemporary Hospitality Management, 13, 30-35.

Dimmock, K., Breen, H. \& Walo, M. (2003). "Management Competencies: An Australian Assessment of Tourism and Hospitality Students". Journal of the Australian and New Zealand Academy of Management, 9(1), 12 - 26.

Fieger, P. (2012). Measuring student satisfaction from the Student Outcomes Survey, National Centre for Vocational Education Research (NCVER), Adelaide.

Fornell, C. (1992). A National Customer Satisfaction Barometer: The Swedish Experience. Journal of Marketing, 56, 621. https://doi.org/10.2307/1252129

Giese, J., \& Cote, J. (2002). Defining Consumer Satisfaction, Academy of Marketing Science Review, Volume 2000 No. 1. Available online at: http://www.amsreview.org/articles/giese01-2000.pdf [Accessed 1 June 2018].

Goodenough, R., \& Page, S. (1993). Planning for Tourism Education and Training in the 1990s: Bridging the Gap between Industries. Journal of Geography in Higher Education, 17(1), 57-73.

Gruber T., Fuß S., Voss R. and Glaser-Zikuda M. 2010. Examining Student Satisfaction with Higher Education Services Using a New Measurement Tool. International Journal of Public Sector Management, 23 (2), pp. 105-123.

Knutson, B. \& Patton, M. (1992). How Prepared am I to Succeed in the Hospitality Industry? What students are telling us'? Hospitality and Tourism Educator, 4(3), 38-43.

Koyuncu, M., Burke, R., Fiksenbaum, L., \& Demirer, H. (2008). Predictors of Commitment to Careers in the Tourism Industry, Anatolia, 19(2), 225-236.

Lee, K., Lee, M., \& Kim, H. (2009). A comparison of student and industry perceptions of the event management curriculum in Korea. Journal of Hospitality, Leisure, Sport \& Tourism Education, 8(2), 60-73.

Mahmoud, R. (2014). Evaluation of Practical Courses from the Perspective of Students of Faculty of Tourism and Hospitality in the University of Jordan, Aqaba Branch. Journal of Management Research, 6(2), 162-176.

Mayaka, M., \& Akama, J. (2007). Systems Approach to Tourism Training and Education: The Kenyan Case Study. Tourism Management, 28, 298-306.

Moscardo, G. (1997). 'Making Mindful Managers: Evaluating methods for teaching problem solving skills for tourism management'. Journal of Tourism Studies, 8(1), 16-23.

Munar, A. \& Montaño, J. (2009). Generic Competences and Tourism Graduates. Journal of Hospitality, Leisure, Sport and Tourism Education, 8(1), 70-84.

Mustafa, M. (2012). The Non-Consonance between Tourism Universities' Programs and the Needs of Tourism Employment in Jordan. International Education Studies, 5(1), 161-171.

Mustafa, M. \& Others (2017). Tuning Middle East \& North Africa: Reference Points for the Design and Delivery of Degree Programs in Tourism; Edited by Mairna Mustafa \& Hamid El Debs, Deusto University Press: Bilbao.

Nielsen, J. (1993). Usability Engineering. Boston: Morgan Kaufmann.

O'Driscoll, F., 2012. What Matters Most: An Exploratory Multivariate Study of Satisfaction among First Year Hotel/Hospitality Management Students. Quality Assurance in Education, 20 (3), pp. 237-258.

Oliver, R. (1997). Satisfaction: A Behavioral Perspective on the Consumer, New York: McGraw Hill.

Solnet, D., Robinson, R., \& Cooper, Ch. (2007). An Industry Partnerships Approach to Tourism Education. Journal of Hospitality, Leisure, Sport and Tourism Education, 6(1), 66-70.

Sultan, P. \& Wong, H.Y., (2012). Service Quality in a Higher Education Context: An Integrated Model. Asia Pacific Journal of Marketing and Logistics, 24 (5), 755-784.

Wang, J., Huyton, J., Gao, X., \& Ayres, H. (2010). Evaluating undergraduate courses in tourism management: A Comparison between Australia and China. Journal of Hospitality, Leisure, Sport \& Tourism Education, 9(2), 46-62.

Zagonari, F. (2009). Balancing Tourism Education and Training. International Journal of Hospitality Management, 28, 2-9.

*** ECSI Technical Committee (1998). European Customer Satisfaction Index Foundation and Structure for Harmonized National Pilot Projects, ECSI.

**** Indiana University School of Education. (2019). The American National Survey of Student Engagement (NSSE), available online at: http://nsse.indiana.edu/html/survey_instruments.cfm (accessed March 5 th 2019).

**** Ipsos MORI. (2019). British National Student Survey (NSS), available online at: https://www.thestudentsurvey. com content/NSS2017_Core_Questionnaire.pdf (accessed March 5th 2019).

*** MOHE. (2017). Statistical Report of Higher Education in Jordan (2015/2016), available online at: http://www.mohe.gov.jo/ar/pages/Statistics.aspx

*** USAID. (2007). A Table of Tourism Educational Establishments in Jordan. An unpublished material prepared by USAID/Jordan Tourism Development Project submitted to the Higher Education Committee of Developing National Accreditation standards for Tourism and Hospitality Higher Education Programs (2010-2011).

Submitted:

02.02.2019
Revised:

16.04.2019
Accepted and published online 07.05.2019 